\title{
A Descriptive Analysis of SRLA Members and the Study of Sport Law in Academia
}

\author{
PAUL J. BATISTA \\ Texas A\&M University \\ $\&$ \\ ANDY PITTMAN \\ Baylor University
}

Although history documents that sporting competitions have been held for thousands of years, the academic discipline relating to the management of sporting events and activities is relatively new, beginning in the $1960 \mathrm{~s}$, and proliferating in the 1980s (Parkhouse \& Pitts, 2005). This discipline has been identified as "sport management," or "sport administration," which entails numerous distinct aspects relating to the operations and business of sport. While these terms are often used interchangeably, according to Parkhouse and Pitts (2005), "sport management" is most commonly used by those involved in the field, and will be used in this article. DeSensi, Kelley, Blanton and Beitel (1990) define "Sport Management" to include "any combination of skills related to planning, organizing, directing, controlling, budgeting, leading, and evaluating within the context of an organization or department whose primary product or service is related to sport and/or physical activity" (p. 33).

Parkhouse and Pitts (2005) state that sport management has existed since the ancient Greek games, while Crosset, Bromage and Hums (1998) identify eighteenth century English sporting clubs as the birthplace of modern sport management.

In the United States, one can scarcely read a newspaper or sporting magazine, or watch sport news on television, without recognizing the impact of legal issues arising in the sport industry. Young (2001) identifies sportsrelated litigation as a multimillion-dollar industry. Personal injury, criminal 
activity, discrimination, constitutional issues, antitrust and labor law, collective bargaining, contract negotiation, defamation, and intellectual property matters are just a few of the many legal aspects affecting sport. In order to address these issues confronting practitioners in the field of sport management, academicians at colleges and universities have established courses designed to educate students on the legal principles applicable to sport. Although these principles could be, and many times are, taught in basic sport management courses such as marketing, management, finance, ethics, governance, etc., the legal aspects of sport is recognized as a separate content area within the sport management core curriculum standards (NASPE, 2000). These standards are contained in the Sport Management Program Review Council (hereinafter "Council") Program Standards and Review Protocol (hereinafter "Standards") established and published under the authority of the Sport Management parent organizations, the National Association for Sport and Physical Education ("NASPE") and the North American Society for Sport Management ("NASSM") (Crosset, et al., 1998).

To gain approval by the Program Review Council, both undergraduate and master's programs in Sport Management must include the study of the legal aspects of sport and cover the specified content areas (NASPE, 2000) The Standards clearly delineate content areas that must be incorporated into sport law courses in both undergraduate and master's degree programs (NASPE) The required content areas for undergraduate courses include: (a) administrative/statutory law; (b) constitutional law; (c) contract law; (d) crowd control and security; (e) legal system; (f) products liability; (g) risk management; and (h) tort law (NASPE). Graduate courses contain the additional content requirements of antitrust/labor law and legal research (NASPE). There are no published standards for sport law courses taught in law schools; therefore, each law school determines the course content of such courses.

At this point, it should be noted that there is no consistency among writers who describe the topic as either "sport" law or "sports" law, and there is further debate whether or not "sport law" exists as a separate substantive field of law (Davis, 2001). Since the NASSM Constitution, and indeed the name of the organization itself, uses the collective singular noun "sport," this article will follow that practice and use the terms "legal aspects of sport," "legal aspects" and "sport law" interchangeably when describing sport law.

Before the imposition of the Standards, there were no clearly established guidelines or standards for sport law courses offered as part of a sport management degree program. During the last two decades, many of the sport law courses in the United States and Canada have been organized and 
developed by members of the Sport and Recreation Law Association ("SRLA"), formerly known as the Society for the Study of the Legal Aspects of Sport and Physical Activity ("SSLASPA"). SRLA is an association consisting primarily of academicians teaching sport law at colleges and universities. The purpose of SRLA is "to further the study and dissemination of information regarding legal aspects of sport and physical activity" (SRLA, 2005). The objectives of SRLA include serving as "a medium for academic growth and development through professional exchange" and assisting "in the development of appropriate curricula content" in the area of the legal aspects of sport (SRLA).

This article seeks to describe SRLA members' involvement in sport law studies, by identifying the academic credentials, professional experience, and research activity of these academicians teaching sport law courses. This study also describes the institutions where sport law courses are being taught, the credentials and publishing records of the instructors, the subject matter of sport law courses, and SRLA members' perceptions of the leading publications in the field of sport law.

In the initial dissertation on sport law courses, Baker (1970) proposed that physical educators should be required to complete a law course, and that tort law should comprise the bulk of that course. Baker's research indicated that no sport law courses were offered in any of the higher education programs investigated. One of his recommendations was that a sport law course should be part of the physical education curriculum in higher education. Twenty-one years later, Pittman (1991) further developed this idea by surveying over 450 members of NASPE and the National Association for Girls and Women in Sport. Each respondent was sent a 14-item questionnaire, which was designed to measure their attitude toward eight legal content areas. Slightly over 400 usable responses were received. The results suggested that an undergraduate sport law course should contain the primary content areas of products liability, risk management, and tort law; secondary content areas of administrative law, constitutional law, and contract law; and a study of the judicial system and legal research if time and resources were available.

Cotten (1990 \& 1991) surveyed university faculty members who had expressed an interest in the legal aspects of sport, seeking "to learn as much as possible about the Sport Law courses currently (in 1990) being taught." The earlier survey by Cotten (1990), with a limited survey size, reported that 15 colleges and universities offered a sport law course only at the undergraduate level, while 21 other institutions offered a course only at the graduate level, and an additional 12 institutions offered a course at both undergraduate and graduate levels. A year later, Cotten surveyed a larger number of faculty 
$(\mathrm{N}=309)$ and found that 82 institutions offered 100 sport law courses, while 134 reported no sport law courses were being taught at their institution (Cotten, 1991).

Eickhoff-Shemek and Evans (2000) surveyed the 153 academic institutions listed in the American College of Sports Medicine's 1999 Directory of Graduate Programs in Sports Medicine and Exercise Science. Of the 94 responses to the question of the importance of legal education, 88 $(94 \%)$ indicated that it was at least somewhat important to include a sport law course in the graduate program, or to insure that graduate students have a background in this area. Their recommendations suggested that more law/legal liability content be added in graduate exercise science (and related areas) academic programs and that more professors be prepared to teach law/legal liability courses.

Although the primary purpose of this survey was to determine the research and publication records of current faculty, as well as opinions on the prestige or impact of identified sport law journals, the survey utilized in this current study adopts the format used in the later Cotten (1991) study to determine if significant changes have occurred in the reported information during the intervening years. Since there was no previous information on the impact of sport law publications, the primary purpose of this part of the study was to identify those publications deemed most prestigious by SRLA members. In addition, although the survey instrument was prepared prior to publication of Young (2001), this study follows her recommendation that further research was needed to determine the academic credentials of sport law faculty and the sub-topics covered in their classes. The results of this study will also be compared to Young's (2001) findings of similar information.

\section{METHOD}

In his survey, Cotten (1991) sent surveys to faculty members ( $N=319)$ who had expressed an interest in sport law in various different manners reported in the article, and received 216 responses for a return rate of $71 \%$. Young (2001) sent surveys to a total of 219 institutions that were either listed by NASSM as having sport management programs, or listed by the National Intramural-Recreation Sports Association ("NIRSA") and the National Recreation and Park Association - Society of Park and Recreation Educators ("NRPA-SPRE") as having a parks and/or recreation program. Young (2001) reports receiving 77 replies for a response rate of $35 \%$.

Young (2001) asserts that there is no single source or directory that lists all undergraduate or graduate sport management programs. Sources such as 
NASSM (2006), AAHPERD (2006) and Sports Market Place Directory (2006) publish lists of sport management programs. However, since SRLA is the only professional association of academicians teaching sport law courses at the undergraduate and graduate levels in colleges and universities in the United States and Canada, the authors decided to limit the survey to this group. (The authors chose not to survey the members of the Section on Law and Sports of the Association of American Law Schools due to the different manner in which sport law is taught in law schools, and since Cotten's original survey did not include law school professors.) Therefore, the results of this survey are limited in scope as a report of information about SRLA members

In fall 2001 and early 2002, surveys were sent to all members of SRLA ( $N=194)$ residing in the United States and Canada as listed on the SRLA website. Surveys were not sent to members of SRLA residing outside North America $(n=2)$. The survey was initially sent via electronic mail with instructions allowing participants to complete the survey online. Additionally, letters were sent by regular mail $(n=71)$ to those members without e-mail addresses, or whose e-mail addresses failed to deliver the survey to the individual respondents.

In order to obtain the most current information, the first survey question asked whether the respondent had taught a sport law course during the two academic years immediately preceding the survey. Responses from participants who had not taught a course within the last two years $(n=24)$ were then excluded. The remainder of the survey contained 21 questions, divided into five sections: (a) institutional information, (b) faculty information, (c) sport law background, (d) research publications and presentations, and (e) ranking publications for impact. The first three sections replicated the Cotten (1991) survey. A sixth section, containing four questions for each sport law course taught by each respective respondent, was also included in the survey design.

\section{RESULTS AND DISCUSSION}

Surveys were completed and returned electronically $(n=76)$ or by regular mail $(n=15)$ for a $47 \%$ return rate. Nine responses were invalid for a variety of reasons resulting in a total usable response of 82 . After excluding those who had not taught a course in the prior two years $(n=24)$, the total usable responses numbered 58 .

The total number of respondents to each particular question varies because not all respondents answered each question on the survey. Percentages were 
rounded to the nearest whole number, accounting for variances above or below $100 \%$ in some instances.

\section{Institutional Information}

Respondents were asked whether they taught at a public or private institution and the enrollment range for undergraduate students. Thirty eight respondents (67\%) taught in public (government-funded) schools, while 19 $(33 \%)$ were employed at private institutions. One respondent chose not to answer this question.

Although over half of the respondents taught at mid-sized institutions (5,001 to 20,000), the distribution among institutions of all sizes demonstrates the diversity of colleges and universities with courses involving the legal aspects of sport. Table 1 shows the undergraduate enrollment range for all institutions at which respondents were employed.

\section{TABLE 1}

Undergraduate Enrollment Range $(\mathrm{n}=55)$

\begin{tabular}{lcc}
\hline Enrollment & Number & Percent \\
\hline$<500$ & 0 & $0 \%$ \\
$501-1,000$ & 1 & $2 \%$ \\
$1,001-2,500$ & 5 & $9 \%$ \\
$2,501-5,000$ & 9 & $16 \%$ \\
$5,001-10,000$ & 10 & $18 \%$ \\
$10,001-20,000$ & 18 & $33 \%$ \\
$20,001-30,000$ & 4 & $7 \%$ \\
$>30,000$ & 8 & $15 \%$ \\
\hline
\end{tabular}

Respondents were asked to identify the classification of their institution based on the Carnegie Classification of Institutions of Higher Education. The classifications used for this study are self-reported, and are based on the classifications in effect prior to the changes made in 2000 by the Carnegie Foundation. The diversity of institutional Carnegie Classifications is shown in Table 2. 


\section{TABLE 2}

Carnegie Classification $(\mathrm{n}=45)$

\begin{tabular}{lcc}
\hline Classification & Number & Percent \\
\hline Research I & 8 & $18 \%$ \\
Research II & 6 & $13 \%$ \\
Doctoral I & 9 & $20 \%$ \\
Doctoral II & 2 & $4 \%$ \\
Master's Coll. \& Univ. I & 6 & $13 \%$ \\
Master's Coll. \& Univ. I & 4 & $9 \%$ \\
Baccalaureate College I & 4 & $9 \%$ \\
Baccalaureate College I & 4 & $9 \%$ \\
Law School & 2 & $4 \%$ \\
\hline
\end{tabular}

To determine the academic departments containing a sport law course, respondents were asked to identify the department in which they taught. Twenty one (40\%) reported teaching in a department of kinesiology (also referred to as physical education) and $15(28 \%)$ reported teaching in a department of sport management (also referred to as sport administration). Additional departments or schools where sport law courses were offered included parks \& recreation (also referred to as tourism) $(n=3,6 \%)$, business $(n=2,4 \%)$, law school $(n=1,2 \%)$ and other $(n=11,21 \%)$. The "other" item represented departments of sport sciences, sport studies, health, and exercise.

Respondents were also asked to report the academic program areas for students taking sport law courses. Although only $28 \%$ of respondents indicated teaching in sport management departments, $56 \%(n=47)$ reported that their students have an academic concentration in sport management. Conversely, while $40 \%$ of instructors taught in a department of kinesiology, only $20 \%$ $(n=17)$ of students had a kinesiology concentration. Other program areas were parks and recreation $(n=10,12 \%)$, business $(n=7,8 \%)$, and law school $(n=3$, $4 \%)$. The number of responses to this question $(n=84)$ is larger than the number of respondents completing surveys $(n=53)$ because participants were asked to indicate all concentration areas that applied to their students.

\section{Faculty Information}

The second area of questioning focused on personal attributes, educational background and employment information of faculty members. The results 
indicated that the majority of the respondents were males, with full-time academic appointments and a terminal degree.

The gender of faculty teaching sport law courses was 41 male $(72 \%)$ and $16(28 \%)$ female, with one person not reporting. Of the 58 respondents, 41 (71\%) completed a doctoral degree (PhD. or EdD.) while $17(29 \%)$ earned a law degree (J.D.). Four respondents (7\%) held both doctoral and law degrees.

Fifty one faculty members (89\%) held full time employment appointments, three $(5 \%)$ were visiting or adjunct faculty, two $(4 \%)$ were part time, and one $(2 \%)$ reported "other" as a faculty appointment. Nine respondents (16\%) reported faculty rank as Professor, 18 (32\%) as Associate Professor, $22(38 \%)$ as Assistant Professor, two (4\%) as primarily teaching, and six (11\%) as Adjunct or Visiting Professor. Percentages do not equal 100 due to rounding.

The educational background of faculty was analyzed to determine in which field of study each faculty member held his or her highest degree. Twenty-two respondents (38\%) designated sport management as the field of study for his or her highest degree, 14 (24\%) identified law, $10(17 \%)$ named kinesiology, four (7\%) listed parks and recreation, and eight (14\%) designated other. The "other" category included education, education administration, exercise physiology and sociology of sport.

\section{Sport Law Background}

Based on the relatively recent identification and creation of sport management as an academic discipline, it is not surprising that some sport law faculty have a limited educational exposure to sport law courses. Further, the faculty members arrive with a mixture of backgrounds and an assortment of professional experiences.

Asked to identify the number of legal aspects of sport courses each respondent completed during his or her formal education, 12 of $57(21 \%)$ completed no courses, 20 (35\%) completed one, 17 (30\%) completed two, five $(9 \%)$ completed three, two (4\%) completed four, and one $(2 \%)$ completed five or more.

The background of faculty teaching legal aspects of sport courses is set forth in Table 3. The row identified as practitioner includes experience such as coaching or teaching school, working in the fitness industry, or working for a sport organization or association. The table also has more than 52 total responses because respondents were asked to answer all that applied. 


\section{TABLE 3}

Years of Practical Experience in Sport Law $(n=52)$

\begin{tabular}{lcccc}
\hline Background & $1-3$ & $4-7$ & $8-14$ & $15+$ \\
\hline Teaching Sport Law $(\mathrm{n}=52)$ & 16 & 17 & 14 & 5 \\
Law Practice $(\mathrm{n}=11)$ & 3 & 2 & 5 & 1 \\
College Professor $(\mathrm{n}=41)$ & 9 & 10 & 10 & 12 \\
Practitioner $(\mathrm{n}=33)$ & 6 & 9 & 11 & 7 \\
\hline
\end{tabular}

In order to stay current on topics included in the legal aspects of sport, faculty members reported that they read articles and attended conferences. Out of 55 respondents, $100 \%$ reported reading journals to stay current, $45(82 \%)$ read law reviews, $36(65 \%)$ attended sport law conferences, and 51 (93\%) attended sport management conferences. When asked how many sport law or sport management conferences per year they averaged attending during the last three years, respondents answered as shown in Table 4.

\section{TABLE 4}

Number of Conferences Attended Per Year During Last 3 Years $(n=54)$

\begin{tabular}{lcccc}
\hline Conference type & 0 & $1-2$ & $3-4$ & $5+$ \\
\hline Sport Law $(\mathrm{n}=54)$ & 8 & 38 & 6 & 2 \\
Sport Management $(\mathrm{n}=52)$ & 9 & 34 & 7 & 2 \\
\hline
\end{tabular}

When asked what activity was the most important event to attend each year in order to remain current on the legal aspects of sport, 37 of 47 (76\%) respondents listed the annual SRLA Conference. Other events mentioned more than once were the Sport Lawyers Association annual conference listed by three $(6 \%)$ respondents, and the annual conference of the American Alliance for Health, Physical Education, Recreation and Dance (AAHPERD) named by two $(4 \%)$. Seven $(15 \%)$ respondents listed "other", including one $(2 \%)$ response each for the Athletic Business Conference, National Sports Law Institute of Marquette University Law School's annual conference, Academy of Legal Studies in Business conference, continuing legal education courses, individual state sport law conferences, sport business conferences, and individual research. 


\section{Course Information}

In order to determine the subject matter being taught in sport law courses, questions were submitted with respect to each course taught by the faculty member. The 57 respondents taught a total of 93 different sport law courses at either the undergraduate, graduate or law school levels. When asked how many different courses each faculty member taught annually, 21 (37\%) reported teaching only one course containing legal aspects, 28 (49\%) taught two courses, six (11\%) taught three courses, and two (4\%) taught four courses. The information reported included only separate and distinct sport law courses, and did not include the same course taught each semester or multiple times during the same semester.

Most of the subject matter covered in the identified courses contained subjects relating primarily (or exclusively) to the legal aspects of sport. The courses titles included terms such as "legal aspects," "sport law," "legal issues" or "risk management," indicating a general coverage of legal topics. However, some courses included legal aspects as part of other content areas, including "facility (or stadium) management," "sport finance," "sport marketing," and "sport management."

Instructors were asked to identify, by student classification, the majority of students enrolled in each of the 93 classes. In $52(56 \%)$ of the courses the students were primarily undergraduate students, in $38(41 \%)$ of the courses the students were primarily graduate students, in one $(1 \%)$ course the students were primarily doctoral students, and in two $(2 \%)$ of the courses the students were law students. It should be noted that the survey was limited to the extent that respondents could not indicate when a combination of these students (i.e., graduate and undergraduate) were enrolled in the same class.

For each course, instructors were asked to identify each content area covered and the amount of time (in percentages) allotted to each respective topic. To determine the subject areas to be listed, the content areas described in Cotten (1991), Pittman (1991), Young (2001) and the Standards (NASPE, 2000) were combined, resulting in the subjects shown in Table 5. Four areas emerged as the most consistently covered content areas: (a) negligence, (b) constitutional law, (c) statutes and (d) risk management. The topic described as "statutes" included study of federal statutes such as Titles VII and IX, the Americans with Disabilities Act, the Age Discrimination in Employment Act, etc. The percentage of time devoted to each identified subject matter in each of the 93 courses is listed in Table 5. 


\section{TABLE 5}

Topics Covered in Each Course (Percentage of Time Allotted) ( $\mathrm{n}=93$ courses)

\begin{tabular}{lccccc}
\hline Content Area & $0 \%$ & $1-9 \%$ & $10-19 \%$ & $20-29 \%$ & $>30 \%$ \\
\hline Legal Process & 20 & 59 & 14 & 0 & 0 \\
Negligence & 12 & 11 & 28 & 29 & 13 \\
Intentional Torts & 20 & 43 & 22 & 8 & 0 \\
Constitutional Law & 25 & 24 & 36 & 6 & 2 \\
Statutes & 14 & 34 & 25 & 15 & 5 \\
Governing Organizations & 45 & 37 & 9 & 2 & 0 \\
Product Liability & 29 & 50 & 13 & 1 & 0 \\
Contract Law & 22 & 37 & 26 & 8 & 0 \\
Risk Management & 15 & 26 & 27 & 18 & 7 \\
Professional Sports & 47 & 32 & 9 & 3 & 2 \\
Amateur Sports & 36 & 31 & 19 & 5 & 2 \\
Media & 59 & 29 & 4 & 1 & 0 \\
Intellectual Property & 49 & 40 & 4 & 0 & 0 \\
Legal Research & 29 & 48 & 12 & 3 & 1 \\
\hline
\end{tabular}

The topics covered in each course as reported in Table 5 are very similar to the content coverage areas found by Cotten (1991). Negligence remains the content area on which faculty members spend most class time. (While negligence is a type of tort, this survey follows Cotten's original format identifying negligence as a separate content area from other types of torts, e.g., intentional torts. In law schools, negligence is not identified separately, but is taught in tort law courses.) Cotten reported that $43 \%$ of respondents spent at least $20 \%$ of class time on negligence, while $45 \%$ of respondents in this survey reported spending at least $20 \%$ of class time on negligence. This survey was consistent with Cotten's findings that the topics on which faculty spend the least amount of time were media (63\% did not cover), intellectual property $(53 \%)$, and professional sports $(51 \%)$.

The primary differences between Cotten (1991) and this survey are (a) the reduction in the amount of class time allotted to study of governing organizations, products liability, and contract law, and (b) the increase in the amount of class time allotted to risk management principles.

With regard to class time reduction, the respondents who reported spending no time covering governing organizations increased from $21 \%$ in 
Cotten to $48 \%$ in this study, and spending no time covering product liability increased from $19 \%$ to $29 \%$. While the number of respondents reporting spending no time on contract law was slightly increased (18\% to $24 \%$ ), the number of respondents reporting spending $1 \%$ - $9 \%$ of class time on contract law decreased from $61 \%$ to $40 \%$. However, it appears that the reduction did not result from covering the subject less, but from covering contract law in more detail. Cotten found that $21 \%$ used $10-29 \%$ of class time on contract law, while this study found the same coverage to be $37 \%$.

The largest area of difference in course content was in the increased attention to risk management. Cotten (1991) found that only $5 \%$ of courses allotted $20 \%$ or more of the course study to risk management, while this study found that $27 \%$ of respondents allotted at least $20 \%$ of the course study material to risk management.

Young (2001) used a different method than Cotten (1991) and this study. Young did not survey faculty members directly, but based her findings on an analysis of course syllabi taken from courses concentrating on the legal aspects of sport. As stated above, the current study did not differentiate graduate and undergraduate courses, while Young's analysis divided course content for both graduate and undergraduate course materials. Young also did not measure the percentage of time spent on each topic in the courses she analyzed, but whether or not the topic was covered at all.

Young's (2001) findings for undergraduate courses consistently reveal less coverage of specific course content in every area. In this study, $83 \%$ of respondents reported covering tort law (negligence, recklessness and intentional torts), while only $77 \%$ listed tort law in the syllabi analyzed by Young. Likewise, this study reports more coverage of administrative/statutory law $(85 \%$ - 70\%), constitutional law $(73 \%-68 \%)$, legal system $(68 \%-64 \%)$, contract law $(76 \%-59 \%)$, risk management $(84 \%-52 \%)$, and products liability $(69 \%-32 \%)$.

Young's (2001) findings for graduate courses reveal much the same pattern, showing less coverage in course syllabi than what is reported in this study on contract law $(76 \%-73 \%)$, Constitutional law $(73 \%-65 \%)$, tort law $(83 \%-63 \%)$, legal system $(68 \%-58 \%)$, risk management $(84 \%-58 \%)$, administrative/statutory law $(85 \%-48 \%)$, legal research $(69 \%-43 \%)$, and products liability $(69 \%-30 \%)$.

\section{Textbooks Used in Classes}

Instructors were asked to identify textbooks or other support materials used by, or provided to, students in each class. The courses were divided into 
three categories based upon the primary classification of students enrolled: undergraduate, graduate and law.

Only two of the classes were taught in law school, with one faculty member supplying personally developed materials, and the other using Hylton \& Anderson, Sports Law and Regulation (1999).

For the remaining 91 undergraduate and graduate courses, the overwhelming textbook choice of the instructors was Cotten, Wolohan \& Wilde, Law for Recreation and Sport Managers, 2nd ed., (or its predecessor, Cotten \& Wilde, Sport Law for Sport Managers), which was used in 41 (45\%) of the courses. All other texts were listed four or fewer times. The frequency of textbook use is illustrated in Table 6. The row labeled as "supplied by professor" represents courses in which the instructor prepared a packet containing the course materials. The row identified as "various" denotes that texts were listed only once each. Two of the courses required the use of two different textbooks, and one response was unusable, resulting in 92 total responses for textbooks used in undergraduate and graduate sport law courses. 


\section{TABLE 6}

Textbooks Used in Courses $(\mathrm{n}=94)$

$\begin{array}{ccc}\begin{array}{c}\text { Undergraduate } \\ (\mathrm{n}=51)\end{array} & \text { Graduate } & \text { Total } \\ (\mathrm{n}=41) & (\mathrm{n}=92)\end{array}$

\begin{tabular}{lllllll}
\hline Author/ Text & Number & Percent & Number & Percent & Number & Percer \\
\hline Cotten, et. al., Law & 20 & $39 \%$ & 21 & $51 \%$ & 41 & $45 \%$
\end{tabular}

for Recreation and

Sport Managers (2nd ed.) ${ }^{\mathrm{a}}$

\begin{tabular}{lrllllll}
\hline Appenzeller, Risk & 3 & $6 \%$ & 1 & $2 \%$ & 4 & $4 \%$ \\
Management in Sport
\end{tabular}

\begin{tabular}{lrllllll}
\hline Carpenter, & Legal & 3 & $6 \%$ & 1 & $2 \%$ & 4 & $4 \%$
\end{tabular}

Concepts in Sport: A

Primer

\begin{tabular}{llllllll}
\hline $\begin{array}{l}\text { Dougherty, } \\
\text { Sport, }\end{array}$ & $\begin{array}{c}\text { et. al., } \\
\text { Physical }\end{array}$ & 2 & $4 \%$ & 2 & $5 \%$ & 4 & $4 \%$ \\
\end{tabular}

Activity, and the Law

(2nd ed.)

\begin{tabular}{lllllll}
\hline Hronek, et. al., Legal & 2 & $4 \%$ & 2 & $5 \%$ & 4 & $4 \%$
\end{tabular}

Liability in

Recreation and

Sports (2nd ed.)

\begin{tabular}{lllllll}
\hline $\begin{array}{l}\text { Wong, Essentials of } \\
\text { Amateur Sports Law }\end{array}$ & $4 \%$ & 1 & $2 \%$ & 3 & $3 \%$ \\
\hline $\begin{array}{l}\text { Yasser, Sports Law } \\
\text { Cases and Materials } \\
\text { (4th ed.) }\end{array}$ & $2 \%$ & 1 & $2 \%$ & 3 & $3 \%$ \\
\hline Fried, Safe at First & 1 & $2 \%$ & 1 & $2 \%$ & 2 & $2 \%$ \\
\hline Supplied by Professor & 2 & $4 \%$ & 0 & $0 \%$ & 2 & $2 \%$ \\
\hline Various & 11 & $22 \%$ & 8 & $20 \%$ & 19 & $21 \%$ \\
\hline No text listed & 3 & $6 \%$ & 3 & $7 \%$ & 6 & $7 \%$ \\
\hline
\end{tabular}

${ }^{\mathrm{a}}$ Includes the 1st edition of this text, Sport Law for Sport Managers. 
These findings are consistent with Young (2001), who reported that the Cotten and Wilde book was the most widely used course text in both graduate and undergraduate courses.

\section{Research Publications}

Due to the recent appearance of sport management as an academic discipline, there is little historic information on the research and publication endeavors of faculty. The first survey section asked each respondent to report his/her average annual number of publications during the preceding three years. The second solicited the respondents' opinions of the prestige of several journals that publish articles on the legal aspects of sport.

Each respondent reported the average number of articles he or she published in four different categories during each of the last three academic years. For example, thirty-seven (70\%) of 53 respondents published an average of at least one journal article each year, 9 (24\%) of 37 respondents published an average of at least one law review article, 17 (39\%) of 44 respondents published an average of at least one short article (such as a comment, case review or book review), and 29 (60\%) of 48 published an average of at least one article for practitioners (articles appearing in a magazine, newsletter, etc.) Only 13 respondents averaged two or more journal articles per year, while no respondent averaged more than one law review article during the preceding three years. The results are shown in Table 7.

\section{TABLE 7}

Average Number of Publications During the Last 3 Years $(n=53)$

\begin{tabular}{lcccccc}
\hline Publication Type & 0 & 1 & 2 & 3 & 4 & $5+$ \\
\hline Journal Articles $(\mathrm{n}=53)$ & 16 & 24 & 8 & 2 & 2 & 1 \\
Law Reviews $(\mathrm{n}=37)$ & 28 & 9 & 0 & 0 & 0 & 0 \\
Comments / Case reviews $(\mathrm{n}=44)$ & 27 & 8 & 5 & 2 & 1 & 1 \\
Article for Practitioners $(\mathrm{n}=48)$ & 19 & 17 & 6 & 1 & 0 & 5 \\
\hline
\end{tabular}

Ranking Publications for Impact

Since no journals dedicated primarily or exclusively to the legal aspects of sport are currently listed in the Citation Index of the Institute of Scientific Information, there has been no convenient, accurate, or readily accessible 
method to determine the most prestigious journals currently publishing sport law articles. ${ }^{1}$

Since there is no formula to determine the "best" journals in sport law, the authors asked the respondents to rate publications to determine the respondents' opinion of the "most prestigious journals in the field of sport law." While this method is open to criticism, it does represent the collective opinion of those involved in teaching and research of the legal aspects of sport. Respondents were asked to list publications based on the following criteria:

Many institutions use journal impact factors when making decisions on tenure and promotion. However, the field of sport law has no journals listed in the Social Science Citation Index. Please rank each of the listed journals (or others you list) according to which you consider the most prestigious journal in the field of sport law in each of the indicated categories.

Your ranking of the most prestigious journal should be assigned number 1, with others in descending order. (For example, the most prestigious journal is 1 , the next most important is 2 , the next is 3 , etc.) You may list as many as you like, but please limit your response to those with which you are personally familiar. The journals are listed in alphabetic order.

The publications were divided into two categories: peer reviewed journals and law reviews. Peer reviewed journals publish scholarly manuscripts that are submitted to experts in the field who evaluate the quality of the article, analyze them for scholarly or scientific credibility, make suggestions to improve the manuscript, and recommend to a journal editor whether to publish or reject the article (WordiQ, 2004). According to Black's Law Dictionary (2004), law reviews are "journal(s) containing scholarly articles, essays, and other commentary on legal topics by professors, judges, law students, and practitioners." Typically, law reviews are published by law schools and are edited by law students under the direction of law faculty members.

Respondents were provided with the names of the 8 journals listed in Table 8, and the 10 law reviews listed in Table 9. The publications were listed in alphabetical order, and respondents were provided space to rank other journals or law reviews in addition to those listed in the survey. Respondents were allowed to rank as many as desired, but were instructed to limit

1. Journals included on the Social Science Citation Index (Thomson Scientific, n.d.) may be found on the Internet at http://scientific.thomson.com $/ \mathrm{mj} 1 /$. 
responses to those with which they were personally familiar. The only unlisted journal mentioned more than once was Strategies, which was listed once as a peer-reviewed journal and once as a law review. ${ }^{2}$ For the purpose of this question and due to the limited response, Strategies was not ranked.

As stated above, each Respondent was instructed to assign a rating of "1" to the publication that he/she perceived to be the most prestigious in each category, a rating of " 2 " to the next most prestigious, etc. In order to avoid using tables to describe responses for each individual publication and to calculate an average for each publication, the responses were ranked on a 10 point scale, with a publication allocated a value of 10 points for each "1" rating, a value of 9 points for each " 2 " rating, etc., continuing to 1 point for each "10" rating. All ratings above $10(n=6)$ were assigned a zero point value.

To determine the total score for each respective publication, the total number of "1" ratings for each publication was multiplied by 10 , the total number of " 2 " ratings was multiplied by 9 , etc. Those totals were then divided by the number of respondents ranking that respective publication to determine the average rating given to a particular publication by the respondents. Table 8 illustrates the results for academic journals, while Table 9 contains the results for law reviews. It should be noted that the Sport Lawyers Journal is limited to articles authored exclusively by American and Canadian law students.

\section{TABLE 8}

Ranking of Sport Law Journals $(n=53)$

\begin{tabular}{lccc}
\hline Publication & Total & Responses & Avg. \\
\hline Journal of Legal Aspects of Sport & 476 & 52 & 9.15 \\
Journal of Sport Management & 359 & 43 & 8.35 \\
Education Law Reporter & 212 & 26 & 8.15 \\
International Journal of Sport Management & 203 & 28 & 7.25 \\
Journal of Physical Education, Recreation \& & 273 & 38 & 7.18 \\
Dance & & & \\
Journal of Park and Recreation Administration & 123 & 20 & 6.15 \\
Journal of Teaching in Physical Education & 75 & 13 & 5.77 \\
The Physical Educator & 74 & 15 & 4.93 \\
\hline
\end{tabular}

2. Strategies is a peer-reviewed journal. 


\section{TABLE 9}

Ranking of Sport Related Law Reviews ( $n=53$ )

\begin{tabular}{lccc}
\hline Publication & Total & Responses & Avg. \\
\hline Marquette Sports Law Review & 444 & 49 & 9.06 \\
Seton Hall Journal of Sport Law & 334 & 41 & 8.15 \\
The Sports Lawyers Journal & 225 & 30 & 7.50 \\
Villanova Sports \& Entertainment Law Journal & 155 & 22 & 7.04 \\
UCLA Entertainment Law Review & 55 & 8 & 6.88 \\
Virginia Journal of Sports and the Law & 141 & 21 & 6.71 \\
Texas Review of Entertainment \& Sports Law & 59 & 9 & 6.56 \\
Florida Entertainment, Art \& Sport Law Journal & 76 & 12 & 6.33 \\
U. of Miami Entertainment \& Sports Law Journal & 93 & 15 & 6.20 \\
Cardozo Arts \& Entertainment Law Journal & 67 & 11 & 6.09 \\
Loyola of Los Angeles Entertainment Law Review & 48 & 8 & 6.00 \\
\hline
\end{tabular}

While only $3(27 \%)$ of the 11 law reviews were ranked by at least half of the respondents, $5(62 \%)$ of the 8 journals were ranked by approximately half of the respondents. Although this study concerns courses involving the legal aspects of sport, this indicates that the respondents are generally more familiar with journals than law reviews. This finding is not surprising since only $29 \%$ of Respondents have law degrees.

\section{Recommendations for Future Study}

It has been more than 14 years since Cotten published his seminal article on the status of sport law courses. During the interim, Cotten's follow-up study, Pittman's dissertation and Young's findings have added to this body of knowledge. Future articles should analyze the results of this prior research and seek to determine the changes in content, if any, during the intervening years. It would be beneficial to determine the sub-topics covered under each content area, in order to determine the specific study topics included in each content area. In order for a neutral source to determine the relative prestige and research impact of the journals and law reviews which focus on sport law, the editors of the various publications should consider seeking recognition in the Social Sciences Citation Index. Finally, any further study of the sport law curriculum should probably be delayed until after the new content standards are determined by NASPE/NASSM in the near future. 
Another area fertile for future study is the manner in which sport law courses are taught. There are many different ways to present classroom material. Questions for additional study could answer the following (or similar) questions: Are students required to read, brief and recite on legal cases in the traditional legal study method, or is the material delivered in lecture format? What type reading and outside class assignments are required? Are students encouraged to search legal web sites or legal research material in law libraries? Are undergraduate and graduate classes taught in the same manner? Are course exams primarily multiple choice/true-false, or primarily essay? Is independent study required in the form of a term paper or oral presentation? Are guest speakers utilized? Are students required to attend the trial of a case at the local courthouse? Are students required to debate a topic or case, or "try" a case? What audio visual aids are employed?

Due to the proliferation of sport law books during the last few years, a study of the subjects contained in the various self-described sport law books would be beneficial. This study could answer the following (or similar) questions: Do the books cover the same content areas, in roughly the same percentages, as listed in Table 5? Do professors limit teaching to the subjects contained in the books, or add other materials to the course content? Do the books include the same content areas, or do different authors highlight varied content areas? Are those books rehashing conventional subjects, or adding new topics reflecting the changes in sport law?

\section{SUMMARY}

According to Parkhouse and Pitts (2005), more than 200 sport management programs exist in colleges and universities in the United States. In order to comply with the NASPE/ NASSM standards, these programs are required to offer a course encompassing the legal aspects of sport. This is entirely appropriate since law permeates sport in the same manner it does every other segment of American society.

As sport management develops and grows as an academic discipline, new courses will be introduced and new faculty will be called upon to design courses in sport law. Building on the earlier work of Baker (1970), Pittman (1991), Cotten (1990 \& 1991) and Young (2001), this study was designed and reported to provide valuable information to instructors teaching courses involving the legal aspects of sport. This information was collected to assist in identifying the subjects to be included in similar courses. Further, the study identifies the attributes of instructors teaching sport law courses, as well as the research and publishing records of faculty teaching courses involving the legal 
aspects of sport. This study also provides guidance to faculty members creating or modifying the course content of sport law courses, and allows SRLA members to evaluate their academic activities compared to their colleagues. Finally, this study demonstrates that course content in sport law courses has not changed substantially since the initial study was reported by Cotten (1991).

\section{ABOUT THE AUTHORS}

PAul J. BAtista is an Associate Professor in the Department of Health and Kinesiology at Texas A \& M University, where he teaches the legal aspects of sport in the Sport Management program. He received his Juris Doctor from Baylor University Law School in 1976, and his B. S. in Business Administration from Trinity University in 1973. He has taught graduate and undergraduate law courses in the Sport Management program at Texas A \& M since 1991. He has practiced law for almost 30 years, and is a former County Judge of Burleson County, Texas. He is admitted to practice before the United States Supreme Court, is licensed to appear in all Texas courts, is a certified Mediator and Arbitrator, and has been elected a Fellow in the Texas Bar Foundation. While at Texas A \& M, Professor Batista has received the Association of Former Students Distinguished Achievement Award in Teaching, and has been named a Montague Center for Teaching Excellence Scholar. He is a member of the Sport and Recreation Law Association, the North American Society of Sport Management, and serves on the Editorial Review Board of the Journal of Legal Aspects of Sport. His primary research interests are sports related liability issues in school settings, and Internet and technology issues in sport law.

DR. Andy PITtMan, Professor and Coordinator of the Sport Management Program at Baylor University, received a B.S. in Physical Education from Baylor University, an M.Ed. in Sports Administration from Ohio University, an M.S. in Taxation from the University of Baltimore, a Ph.D. in Higher Education administration from Texas A\&M University, and has taken postdoctoral work at Baylor University Law School. He has been employed at Baylor University since 1981. He is a member of several professional organizations including AAHPERD, Kappa Delta Pi, National Sports Law Institute of Marquette University Law School, NASSM, Omicron Delta Kappa, Phi Delta Kappa, SRLA, the Sports Lawyers Association and the Women's Sports Foundation. He has over 50 refereed presentations at the 
state, district, national, and international levels. He has published journal articles in the Facility Manager, Journal of Legal Aspects of Sport, Journal of Physical Education, Recreation, and Dance, Research Quarterly for Exercise and Sport, and West's Education Law Reporter, authored or co-authored 8 book chapters, and co-authored a legal casebook and a risk management text. He has held many leadership positions in several professional organizations at state and national levels. He is the Law Section Editor of the Journal of Physical Education, Recreation, and Dance. He is the recipient of the Honor Award and two-time recipient of the Presidents Award from SSLASPA (now SRLA) and was recognized for his 7 years as newsletter editor for SSLASPA. $\mathrm{He}$ is the 2005 recipient of the Presidential Citation Award and a 2006 corecipient of the Distinguished Scholar Award from the School and Safety Community Safety Society of America. Dr. Pittman has also received the Leadership Award and the Faculty Achievement Award from the Baylor University School of Education and was named to the Norman "Moon" Mullins Distinguished Honor Roll for Faculty and Staff by Baylor University.

\section{REFERENCES}

AAHPERD (2006). Sport management program review approved programs January 2006. Retrieved June 12, 2006, from http://www.aahperd.org/naspe/ pdf_files/approvedPrograms06.pdf

Baker, B. B. (1970). Physical education and the law: A proposed course for the professional preparation of physical educators. Unpublished doctoral dissertation, University of Oregon, Eugene.

Black's Law Dictionary (8th ed. 2004).

Cotten, D. J. (1990). A survey of sport law courses. In J. W. Merriman \& J. H. Conn (Eds.), Proceedings of the Third Annual Sport, Physical Education, Recreation, and Law Conference, (pp. 133-139), Jekyll Island, Georgia.

Cotten, D. J. (1991). Current status of sport law courses. Journal of Legal Aspects of Sport, 1, 50-56.

Crosset, T.W., Bromage, S., \& Hums, M.A. (1998). History of sport management. In L. P. Masteralexis, C. A. Barr \& M. A. Hums (Eds.), Principles and practice of sport management (pp. 16-17). Gaithersburg, MD: Aspen Publishers.

Davis, T. (2001). What is sports law? Marquette Sports Law Review, 11, 211244. 
DeSensi, J., Kelley, D., Blanton, M., \& Beitel, P. (1990). Sport management curricular evaluation and needs assessment: A multifaceted approach. Journal of Sport Management, 4(1), 31-58.

Eickhoff-Shemek, J. \& Evans, J. (2000). An investigation of law and legal liability content in master academic programs in sports medicine and exercise science. Journal of Legal Aspects of Sport, 10(3), 172-179.

Gottlieb, R. (Ed.). (2006). Sports market place directory. Millerton, NY: Grey House Publishing.

Hylton, J.G. \& Anderson, P.M. (Eds.) (1999). Sports law and regulation. Milwaukee, Wisconsin: Marquette University Press.

NASSM (2006). Sport management programs. Retrieved June 12, 2006 from http://www.nassm.com/InfoAbout/SpoortMgmtPrograms.

NASPE (2000). Sport management program standards and review protocol. Oxon Hill, MD: AAHPERD.

Parkhouse, B. \& Pitts, G. (2005). The history of sport management. In B. L. Parkhouse (Ed.), The management of sport: Its foundation and application (pp. 2-14). New York: McGraw Hill Higher Education.

Pittman, A.T. (1991). Sports law: Essential content areas for the undergraduate physical education curriculum. (Doctoral dissertation, Texas A \& M University). Dissertation Abstracts International, 53/01, 99A.

SRLA: Sport and Recreation Law Association (2005). Mission Statement. Retrieved June 5, 2006, from http://www.srlaweb.org/mission_ statement.html

Thomson Scientific (n.d.). Master journal list. Retrieved June 5, 2006, from http://scientific.thomson.com/mjl/.

WordiQ.com (2004). Retrieved May 8, 2006, from http:/www.wordiq.com/ definition/Peer_review

Young, S. J. (2001). A content analysis of legal aspects courses in sport management. Journal of Legal Aspects of Sport, 11(3), 225-243. 


\title{
Sport \& Recreation Law Association 20th Annual Conference February 28-March 3, 2007 - Chapel Hill, NC
}

\author{
We hope to see you there! \\ For more information visit the conference website \\ the SRLA website at http://www.srlaweb.org/ \\ and look under Conference Info.
}

The 2007 conference is scheduled for February 28 - March 3. Hosted by the University of North Carolina at Chapel Hill in the beautiful and historic Carolina Inn, the 20th Anniversary conference will include a Welcome Reception on Wednesday evening with a Beach Party theme to honor the first conference at Jeckyll Island! Featured speakers and research presentations will begin on Thursday morning and continue through Saturday afternoon. More information on the conference will soon be available on the SRLA website at www.srlaweb.org or contact Barbara Osborne at sportlaw@unc.edu. 


\section{GUIDELINES FOR AUTHORS}

The Journal of Legal Aspects of Sport is a peer-reviewed and copyrighted professional journal intended to meet the needs of sport law educators and to serve as a forum for legal issues related to clubs, fitness, health \& wellness, physical activity, recreation and sport.

\section{PART ONE: SUBMISSIONS}

Submissions can be sent by email to the Editor, Professor Paul Anderson at paul.anderson@mu.edu.

Submissions can also be sent by regular mail to:

Professor Paul Anderson

Editor, Journal of Legal Aspects of Sport

National Sports Law Institute

Marquette University Law School

1103 W. Wisconsin Ave., P.O. Box 1881

Milwaukee, WI 53201-1881

\section{PART TWO: SUBMISSION REQUIREMENTS}

(1) Email submissions:

A manuscript submission by email should include

(a) Within the email: The author(s) name, contact information, and biographical information. This information should not appear anywhere within the attached manuscript.

(b) Attached to the email: The manuscript itself.

(c) The information below under \#3 "All Submissions."

(2) Submission by Mail

A manuscript submission by mail should include:

(a) A cover letter that includes the author(s) name, contact information and biographical information. Do not include any of this information within the manuscript.

(b) One (1) printed copy of the manuscript.

(c) A copy of the manuscript submission on a $31 / 2$ inch disc or CDRom in a Microsoft Word compatible format.

(d) The information below under \#3 "All Submissions." 
(3) All submissions:

(a) Citation format, either

LEGAL STYLE (footnotes), following the Harvard Citator/ Bluebook (18th Edition, 2005)

or,

APA STYLE (textual citations), following the Publication Manual of the American Psychological Association (5th Edition, 2001).

(b) At the end of the manuscript create a reference list that includes references to all sources referred to in the manuscript. This reference list must be in APA format (5th Edition, 2001).

(c) Include any website address in normal text. Do not include any hyperlinked text within any manuscript.

(d) Format the article using indent and paragraph formatting functions only. Do not insert extra tabs or paragraph marks within the submission and do not use any outline formatting program.

(e) For all article citations included within the reference list be sure to include a full page range and issue number. [This information cannot be found on Westlaw or Lexis\}.

(f) Include the editions or volume of a book or other publication in normal font, i.e., 4 th ed. is correct. Do not include this information in superscript font.

(g) Upon the request of the Editor, authors must be able to provide all sources referred to in the article for verification purposes. Authors should save their research until the review process is complete.

(h) If the article includes graphs, charts, tables or other graphics please include them as separate documents or at the end of the document after the reference list. In addition, include notes within the text as to where the graphics should appear.

(i) Do not include an abstract within any manuscript.

\section{PART THREE: REVIEW PROCESS}

(1) Once a submission is received, the Editor will contact the author to certify that the manuscript complies with all of these Guidelines.

(2) All submissions are reviewed by the Editor and three selected members of the Editorial Review Board chosen by the Editor. 
(3) Upon receipt of a submission by the Editor, the article review process will normally last approximately 6 weeks.

\section{(4) Review Standards}

The Journal of Legal Aspects of Sport endeavors to publish submissions of the highest scholarly quality in terms of novelty, writing, research, methodology and interest to the academic world, sport management and sports law professionals.

Categories that are of particular importance include:

i. Proper use of APA or Bluebook style.

ii. Quality of Writing (Is the article readable with good transitions with few mistakes in word tense, grammar, spelling and sentence structure?)

iii. Organization, reasoning and analysis (Does the author present a reasoned and organized legal analysis of the topic? Does the author present the topic in an easy to understand, logical manner?)

iv. Quality of research (Has the author thoroughly researched the topic area, or do you know of other sources they should have used in their paper?)

v. Novelty and uniqueness of the topic (Has this topic been covered before in other articles so that the author just restating what has come before? Or, has the author presented a new and novel look at the topic?)

(5) All publication decisions are made by the Editor after consideration of reviewer comments and the factors above. Authors can expect to receive one (1) of the following three (3) responses:

Accept the article for publication with minor edits

Do not accept the article

Send the article back to the author with reviewer comments and allow for resubmission.

(6) All publication decisions are final and are not reviewable. 


\section{Sport and Recreation Law Association}

\section{MEMBERSHIP \& ORDERING}

Website: www.srlaweb.org

\section{Membership Benefits}

Newsletter - a bi-monthly newsletter is published six (6) times per year on the SRLA website. It provides SRLA updates, recent cases, law journal article citations pertaining to sport and physical activity, and book reviews.

Journal - The Journal of Legal Aspects of sport is published 2 times per year in winter and summer.

Subscriptions to the Journal of Legal Aspects of Sport alone are also available for $\$ 15.00$ an issue or $\$ 45.00$ annually. To order the Journal please contact Lori Miller, SRLA Executive Director, c/o Mary Myers, Journal of Legal Aspects of Sport, Wichita State University, Campus Box 16, 1845 Fairmount, Wichita, KS 672600016. PHONE: (316) 978-3340; FAX: (316) 978-5451; EMAIL: mary.myers@wichita.edu.

Annual Conference - An annual conference providing the unique opportunity to network, present, discuss, and learn about the law and how it relates to sport and physical activity.

Memberships - all include the benefits listed above:

$\$ 75.00 \quad$ Professional

$\$ 35.00 \quad$ Student (Registrar's Certification Required)

$\$ 55.00 \quad$ Emeritus

$\$ 95.00$ Institution/Library (+ \$30 international postage when applicable)

Additional postage of $\$ 30.00$ is charged for international subscribers as appropriate.

MEMBERSHIP APPLICATION

(merely photocopy this form and mail to the address below)

Name

Institution/Organization

Address 1

Address 2

Phone

E-mail

Membership category (Check 1): __ Student___ Professional__ Institution

Mail form and Payment (Check or money order) to : Lori Miller, SRLA Executive Director, c/o Mary Myers, Journal of Legal Aspects of Sport, Wichita State University, Campus Box 16, 1845 Fairmount, Wichita, KS 67260-0016. PHONE: (316) 978-3340; FAX: (316) 978-5451; EMAIL: mary.myers@wichita.edu. 


\section{Sport and Recreation Law Association}

President: Rebecca Mowrey

Millersville University

President-Elect: Colleen Colles

Nichols College

Past President: Linda Schoonmaker

Winthrop University

Secretary: Paul J. Batista

Texas $A \& M$ University

Treasurer: Colleen McGlone

University of New Mexico

Member at Large: Stacey Altman

East Carolina University

Member at Large: Barbara Osborne University of North Carolina

Student Representative: Nathan Martin

University of New Mexico

Executive Director: Lori Miller

Wichita State University

SSLASPA dba the SPORT \& RECREATION LAW ASSOCIATION - is a nonprofit corporation. Our purpose is to further the study and dissemination of information regarding legal aspects of sport and physical activity. The Association addresses legal aspects of sport and physical activity within both the public and private sectors. The objectives of the Association are:

(1) to serve as a medium for academic growth and development through professional exchange;

(2) to provide service functions for SRLA members through conference presentations and research publications;

(3) to assist in the development of appropriate curricula content;

(4) to cooperate closely with allied national and international organizations in areas such as athletics, education, exercise, law, medicine, recreation, and sport; and

(5) to network and provide a forum for discussion about the law. 
The Membership of the Sport \& Recreation Law Association wishes to commend

\title{
Paul Anderson
}

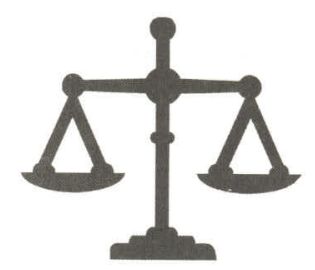

For his unwavering leadership, dedication and commitment to excellence

\author{
as Editor of the
}

Journal of Legal Aspects of Sports 